\title{
ע Kenen päätös? Toimijoiden asemat ja tiedolliset auktoriteetit HPV-rokotuskeskustelussa
}

HPV-rokotteen avulla pyritään ehkäisemään ihmisen papilloomavirusten tartuntaa ja niiden aiheuttamia haittoja, erityisesti kohdunkaulan syöpiä. Suomessa rokotetta tarjotaan nuorille maksutta osana kansallista rokotusohjelmaa. Tässä tutkimuksessa tarkastellaan HPV-rokotteeseen liittyviä puhetapoja keskittyen kahteen päätöksentekoon liittyvään kysymykseen: I. Ketkä ovat keskeisiä toimijoita HPV-rokotuspäätöksen tekemisessä ja millaisia ovat heidän asemansa? 2. Millaisiin tiedollisiin auktoriteetteihin HPV-rokotukseen liittyvässä keskustelussa vedotaan? Tutkimuksen aineistona toimivat HPV-rokotukseen liittyvät uutisartikkelit sekä nuorten ja aikuisten verkkokeskustelut, joita on analysoitu asemointianalyysin avulla. Tulokset osoittavat, että aktiivisiksi päätöksentekijöiksi asemoidaan vaihtelevasti nuori, tämän vanhemmat ja terveysviranomaiset. Keskustelussa ilmenee lisäksi jännitteitä erilaisten tiedollisten auktoriteettien välillä. Keskeisiksi nousevat biolääketieteellinen, institutionaalinen, kokemuksellinen ja yksilöllinen kognitïvinen auktoriteetti, joiden asemaa vahvistetaan ja haastetaan eri tavoin osana keskustelua. Tutkimus korostaa tarvetta tarkastella rokotuspäätöstä usean toimijan jaettuna päätöksenä.

\section{ASIASANAT: rokotteet, päätöksenteko, diskurssi, tiedonlähteet}

\section{NOORA HIRVONEN}

\section{YDINASIAT}

- Aikaisempi suomalainen tutkimus korostaa nuoren aktiivista asemaa HPV-rokotuspäätöksentekijänä.

- Analysoiduissa uutisartikkeleissa ja verkkokeskusteluissa päätöksentekijän asemaan asetetaan vaihdellen nuori, tämän vanhemmat ja terveysviranomaiset.

- Biolääketieteellisen tiedon lisäksi keskustelussa vedotaan vakiintuneisiin instituutioihin, kokemustietoon ja omaan päättelyyn perustuvaan kognitiiviseen auktoriteettiin.

- Tulevissa tutkimuksissa on syytä tarkastella jaettua rokotuspäätöksentekoa.

\section{JOHDANTO}

HPV-rokotteen avulla pyritään ehkäisemään ihmisen papilloomavirusten tartuntaa ja niiden aiheuttamia haittoja. Papilloomavirusinfektio voi kehittyä kohdunkaulan, emättimen ja ulkosynnytinten syöväksi ja papilloomavirukset aiheuttavat lisäksi osan peräaukon, peniksen sekä pään ja kaulan alueen syövistä (1). Suomessa HPV-rokote on ollut kansallisessa rokotusohjelmassa vuodesta 2013 (2). Se poikkeaa useimmista rokotusohjelman rokotteista useilla tavoilla: se tähtää syövän ehkäisemiseen, suojaa lähinnä seksuaalisessa kanssakäymisessä tarttuvalta virukselta ja vuoteen 2020 asti rokotetta tarjottiin ainoastaan tytöille. Poikkeuksellista on lisäksi se, että HPV-rokotteen kohteena ei ole pieni lapsi, vaan nuori, joka itse voi osallistua rokotuspäätöksen tekemiseen. Rokotteen erityisyys ilmenee myös rokotuskattavuudessa; vaikka Suomessa rokotuskattavuus on yleisesti kansainvälisesti verrattuna erittäin korkealla tasolla, HPV-rokotuksen suhteen alueelliset erot ovat merkittäviä (3).

Vaikka lääketieteellisessä tutkimuskirjallisuudessa näyttöä HPV-rokotteiden turvallisuudesta 
pidetään kiistattomana (1), rokotusohjelman alkuvaiheessa puhuttiin jopa "rokotekohusta" kun sosiaalisessa mediassa levinneet väitteet rokotteen vakavista haittavaikutuksista nousivat julkiseen keskusteluun (4). Rokotetta kritisoineet puheenvuorot kyseenalaistivat paitsi rokotteen turvallisuuden, myös rokotetoiminnasta vastaavien tahojen luotettavuuden. Kansainvälisissä tutkimuksissa epäluottamus terveysviranomaisiin, terveydenhuollon ammattilaisiin ja uusiin rokotteisiin on tunnistettu sivuvaikutuksiin liittyvien huolten ohella keskeiseksi tekijäksi HPV-rokotetta koskevan epäröinnin taustalla (5).

HPV-rokotteen yhteydessä keskustelua on herättänyt lisäksi nuoren ja vanhempien asema rokotukseen liittyvässä päätöksenteossa (6). Suomessa rokoteohjelman alussa rokotetta tarjottiin 11-15 -vuotiaille tytöille, ja Terveyden ja hyvinvoinnin laitoksen (THL) linjauksen mukaan alle 12-vuotiaan rokottamiseen tuli saada suostumus huoltajalta. Sitä vanhempi nuori voitiin kuitenkin rokottaa nuoren omasta toiveesta myös ilman huoltajan lupaa, mikä herätti vastustusta (6). Tällä hetkellä rokotetta tarjotaan aikaisempaa nuoremmille, 10-12-vuotiaille, tytöille ja myös pojille (7). Vanhemmalta tai nuorelta ei enää vaadita erillistä suostumusta rokottamiseen, mutta huoltajalla on edelleen oikeus kieltää rokotteen antaminen, eikä rokotetta anneta minkään ikäiselle nuorelle vastoin tämän omaa tahtoa (7).

Tämän informaatiotutkimuksen alaa edustavan laadullisen tutkimuksen tavoitteena on lisätä ymmärrystäHPV-rokotuskeskustelussa ilmenneistä jännitteistä keskittymällä kahteen päätöksentekoon liittyvään kysymykseen:

1. Ketkä ovat keskeisiä toimijoita HPV-rokotuspäätöksen tekemisessä ja millaisia ovat heidän asemansa?

2. Millaisiin tiedollisiin auktoriteetteihin HPVrokotukseen liittyvässä keskustelussa vedotaan?

Tutkimuksen aineistona toimivat suomalaiset HPV-rokotteeseen liittyvät uutisartikkelit ja verkkokeskustelut. Niiden avulla tarkastellaan tapoja, joilla rokotuspäätöksenteon kannalta keskeisten toimijoiden ja päätöksentekoa ohjaavien tiedonlähteiden asemaa rakennetaan kielellisesti. Artikkelissa esitetään, että HPV-rokotekeskustelussa ilmenevät jännitteet kytkeytyvät sekä päätöksentekijöiden ristiriitaisiin asemiin että erilaisiin tiedollisiin auktoriteetteihin.

\section{AIKAISEMPI TUTKIMUS}

\section{TOIMIJOIDEN ASEMAT HPV-ROKOTUSPÄÄTÖKSENTEOSSA}

Tässä tutkimuksessa huomio kiinnittyy tapoihin, joilla HPV-rokotuspäätöksentekoon osallistuvien toimijoiden asemia rakennetaan kielellisesti sijoittamalla heitä määrättyihin rooleihin tai tietyn näkökulman edustajiksi. Asemat eivät ole pysyviä, vaan ihminen voi asemoida itseään ja toisia eri tavoin eri tilanteissa, ja toimijat voivat saada vaihtelevia ja ristiriitaisiakin asemia (8). Stabiilimman rooli-käsitteen sijaan asemointi korostaakin tilannekohtaisuutta tavoissa, joilla ihmiset tuottavat itsestään ja toisistaan sosiaalisia olentoja $(8,9)$.

Tutkimusta taustoittavat aikaisemmat tutkimukset, joissa on tarkasteltu toimijoiden asemia HPV-rokotetta koskevissa kampanjamateriaaleissa, mediassa ja rokotuspäätökseen osallistuneiden haastatteluissa. Näissä tutkimuksissa on tunnistettu kolme keskeistä päätöksentekoon osallistuvaa toimijaryhmää - nuoret, vanhemmat ja terveydenhuollon ammattilaiset $(10,11,12)$. Virtasen (13) mukaan suomalaisessa HPV-rokotekampanjassa on korostunut tyttöjen aktiivinen asema. Kampanja kohdistettiin ensisijaisesti tytöille ja sen materiaaleissa tytöt kuvatiin rationaalisina yksilöinä, jotka voivat suojautua tappavalta syövältä tekemällä oikean valinnan: ottamalla rokotteen. Rokotteen ottamatta jättäminen sen sijaan kehystettiin epärationaaliseksi ja vastuuttomaksi valinnaksi. Kampanjamateriaalien lisäksi Virtanen (13) tarkasteli tyttöjen verkkokeskusteluja, ja huomioi, että myös niissä näkyi tyttöjen aktiivinen asema päätöksenteossa: tytöille ja nuorille naisille suunnatulla Demi-foorumilla nuoret tytöt pohtivat rokotuspäätöstä vertaistensa kanssa (13). Tyttöjen aktiivinen asema on painottunut myös ruotsalaisessa (14) ja australialaisessa (10) HPV-rokotekampanjoinnissa; kampanjoiden on todettu painottavan rokottautumista tytön henkilökohtaisena valintana (10) ja voimaantumisen mahdollisuutena (14).

Australialaisten $(10,11)$ ja kanadalaisten (12) nuorten, vanhempien, opettajien ja terveydenhuollon ammattilaisten haastatteluihin perustuvat tutkimukset löytävät nuorille myös muita kuin aktiivisen päätöksentekijän asemia: Railin ym. (12) ja Cooper Robbinsin ym. (11) tutkimusten mukaan sekä tytöt (12) että vanhemmat tavallisesti asemoivat rokotuspäätöksen tekijäksi vanhemman, tyypillisesti äidin. Usein nuori kuitenkin oli 
mukana päätöksenteossa, ja päätöksentekoon liittyi myös jännitteitä: nuori saattoi esimerkiksi kieltäytyä rokotteesta vanhempiensa päätöksen vastaisesti (11). Lefevre ym. (15) huomauttavat että vaatimus vanhemman hyväksyntään vahvistaa tyttöjen passiivista asemaa. Keskeinen huomio aikaisemmissa tutkimuksissa on lisäksi se, että rokottamiseen liittyvät käytännöt eivät usein niinkään ohjaa nuorta tai vanhempaa aktiiviseen päätöksentekoon, vaan rutiininomaiseen rokotuksen vastaanottamiseen $(10,11)$.

Aikaisempi kansainvälinen tutkimus viittaa siihen, että rokotuspäätökseen osallistuu potentiaalisesti useita eri toimijoita, joiden asemat päätöksentekijöinä voivat olla epäselviä. HPV-rokotteen kohdalla tapoja, joilla päätöksentekijöiden asemaa rakennetaan eri konteksteissa ei ole Suomessa aiemmin tutkittu Virtasen (13) tyttöjen asemaan keskittynyttä analyysia lukuun ottamatta. Keskustelusta on toistaiseksi puuttunut lisäksi rokotuspäätöksen perusteluun käytettyjen tiedollisten auktoriteettien tarkastelu.

\section{HPV-ROKOTE JA KOGNITIIVINEN AUKTORITEETTI}

Rokotuspäätöksen kannalta keskeiseksi nousevien tiedonlähteiden aseman tarkasteluun hyödynnetään tutkimuksessa kognitiivisen auktoriteetin (cognitive authority) käsitettä (16). Se viittaa luotettavana pidettyyn tiedonlähteeseen, jonka puoleen käännytään tiedontarpeen ilmetessä ja jolla on vaikutusta ajatteluun $(16,17)$. Kognitiivinen auktoriteetti perustuu pikemminkin tiedonlähteen tunnistettuun asiantuntemukseen ja luottamukseen kuin valta-asemaan, ja on suhteessa tiettyyn tiedon alueeseen $(16,17)$. Kognitiivista auktoriteettia voi olla paitsi henkilöllä, myös esimerkiksi instituutiolla tai dokumentilla (16).

Aikaisemman konstruktionistiseen näkökulmaan sitoutuneen tutkimuksen mukaisesti kognitiivinen auktoriteetti ymmärretään tässä tutkimuksessa yhteisöllisesti rakennettuna; eri yhteisöissä tunnistetaan erilaisia auktoriteetteja, joiden asemaa jatkuvasti vahvistetaan tai haastetaan eri keinoin $(16,17)$. Kognitiivinen auktoriteetti ei niinkään kuvaa olemassa olevia uskomuksia tai asenteita, vaan toimii esimerkkinä arkielämän kontekstisidonnaisesta faktojen rakentelusta (17, 18). Tiedonlähteen auktoriteettiasemaa voidaan vahvistaa muun muassa vetoamalla tietynlaiseen tietoon etuoikeuden antavaan puhujakategoriaan, esimerkiksi ammattiin tai kokemukseen perustu- vaan asemaan, tai rakentamalla faktuaalista konsensusta viittaamalla useisiin samaa väitettä tukeviin lähteisiin $(17,18,19)$. Lähteen auktoriteettiasemaa voidaan horjuttaa esimerkiksi osoittamalla sen epäsopivia intressejä tai muita virhelähteitä $(17,18,19)$.

Tässä tutkimuksessa tukeudutaan erityisesti terveyden kognitiivisia auktoriteetteja käsitteleviin tutkimuksiin, joissa on tarkasteltu lääketieteen ja sen edustajien biolääketieteellisen kognitiivisen auktoriteetin suhdetta muihin tietämisen tapoihin $(17,20)$. Artikkelissa käytetään lisäksi institutionaalisen kognitiivisen auktoriteetin käsitettä viittaamaan luottamukseen yhteiskunnallisten toimijoiden, kuten median ja virkamiesten, välittämää informaatiota kohtaan. Aikaisempi potilaan ja terveydenhuollon ammattilaisen suhteeseen keskittynyt tutkimus osoittaa, että biolääketieteellistä kognitiivista auktoriteettia haastetaan erityisesti vetoamalla muiden kokemuksiin perustuvaan kokemukselliseen kognitiiviseen auktoriteettiin ja toisaalta omaan päättelyyn, kehollisiin tuntemuksiin tai kokemuksiin perustuvaan yksilölliseen kognitiiviseen auktoriteettiin (17). Nämä kognitiivisen auktoriteetin muodot ovat nousseet keskeisiksi myös rokotekeskusteluihin kohdistuneissa tutkimuksissa: Dotyn (19) tarkastelemissa rokotteiden turvallisuuteen keskittyvissä verkkoteksteissä omaan järkeilyyn perustuva yksilöllinen kognitiivinen auktoriteetti esitettiin usein muita ylempiarvoisena tietämisen tapana. Man ja Stahlin (21) tutkimuksessa vanhemmille tarkoitetusta rokotevastaisesta Facebook-ryhmästä sen sijaan korostui kokemuksellinen kognitiivinen auktoriteetti, jota tautologinen, yksinomaan rokotuskriittistä näkemystä edustavien lähteiden esittäminen vahvisti (21).

Genuisin (22) tutkimus jäsentää kiinnostavalla tavalla päätöksentekijöiden aseman ja kognitiivisten auktoriteettien suhdetta. Hän tarkasteli naisten tapaa asemoida itseään suhteessa terveydenhuollon ammattilaisiin ja tiedonlähteisiin ja havaitsi, että useimmat naiset asemoivat itsensä itsenäisiksi päätöksentekijöiksi ja vastuuseen myös tiedonhankinnasta. Tähän asemaan liittyi yksilöllisen kognitiivisen auktoriteetin korostaminen ja terveydenhuollon ammattilaisten asettaminen oppaan tai konsultin asemaan. Biolääketieteellisen tiedon auktoriteettiasemaa painottava puhe sen sijaan asetti terveydenhuollon ammattilaiset sekä kognitiivisen auktoriteetin että pää- 
töksentekijän asemaan, jolloin potilaan asema näyttäytyi ammattilaisesta riippuvaisena. Jaettua päätöksentekoa kuvaava puhe ilmensi molemminpuolista arvostusta erityyppiseen tietoon ja kognitiiviseen auktoriteettiin (22).

Aikaisempi terveyden kognitiivisia auktoriteetteja tarkastellut tutkimus tuo esiin tapoja, joilla biolääketieteellistä kognitiivista auktoriteettia haastetaan tai täydennetään vetoamalla muihin tietämisen tapoihin. Kognitiivisten auktoriteettien tarkastelu suhteessa päätöksentekijäasemaan on kuitenkin ollut vähäistä, eikä aikaisemmissa tutkimuksissa ole huomioitu asetelmia, joissa päätöksentekoon voi osallistua useita toimijoita. Tässä tutkimuksessa päätöksentekijöiden asemien ja kognitiivisten auktoriteettien rakentumista tarkastellaan osana HPV-rokotteesta käytävää keskustelua.

\section{MENETELMÄT}

Tutkimuksen aineistona käytetään HPV-rokotukseen liittyviä uutistekstejä sekä nuorten ja aikuisten verkkokeskusteluja. Aineistot kerättiin tammimaaliskuussa 2020 Yleisradion verkkosivuilta (toimitettu materiaali), kahdelta keskustelufoorumilta (tytöille ja nuorille naisille suunnatulta Demifoorumilta ja Suomi24-foorumilta) sekä Kalevasanomalehden verkkosivuilta (Juttutupa-keskustelualueen kommentit ja lukijakommentit toimitettuun materiaaliin).

Aineiston valinnan taustalla oli ajatus erilaisten tekstityyppien ja keskustelukontekstien sisällyttämisestä tutkimukseen: uutisartikkeleiden voi katsoa edustavan HPV-rokotteesta käytävää julkista keskustelua, jota erilaiset journalistiset konventiot ohjaavat; anonymiteetin mahdollistavien keskustelufoorumeiden ja uutisten kommenttiosioiden sisällön tarkastelu sen sijaan voi paljas- taa puhetapoja, jotka eivät tavallisesti tule esiin julkisuudessa. Lisäksi tarkoituksena oli kerätä aineistoa, joka sisältäisi sekä toimijoiden itselleen tuottamia asemia että näille tuotettuja asemia. HPV-rokotteen kohdalla alueelliset erot rokotekattavuudessa ovat merkittäviä (3), mikä perustelee paikallista näkökulmaa edustavan aineiston valintaa: pohjoissuomalaisen Kaleva-sanomalehden verkkokeskustelujen katsottiin toimivan esimerkkinä erityisesti tietyllä maantieteellisellä alueella ilmenevästä puheesta ja täydentävän muuta, valtakunnallisesti kattavampaa aineistoa.

Laajempi aineisto sisältää kaikki mainituilta sivustoilta löydetyt HPV-rokotetta käsittelevät tekstit ja viestiketjut (ks. Taulukko 1). Laajemman aineiston alustavan analyysin perusteella aineistosta osa valittiin tarkempaan tarkasteluun. Alustava analyysi keskittyi teksteissä mainittuihin toimijoihin ja tiedonlähteisiin. Aineisto rajattiin kattamaan vuodet 2013-2020 (rokotusohjelman alusta aineistonkeruuajankohtaan), ja tarkasteluun valittiin uutisia ja viestiketjuja siten, että suppeampi aineisto oli ajallisesti edustava, mutta myös näkökulmallisesti monipuolinen. Koska tavoitteena oli näkökulmien monipuolisuus, ei suppeampi aineisto sellaisenaan edusta laajempaa aineistoa, eikä sen perusteella voida suoraan tehdä päätelmiä esimerkiksi tiettyjen asemointien dominoivuudesta.

Aineistotyypit nimettiin niiden sisällön ja muodon perusteella uutisaineistoksi (Ylen uutisartikkelit), nuorten verkkokeskusteluiksi (Demifoorumin keskustelut) ja aikuisten verkkokeskusteluiksi (Suomi24-foorumin keskustelut ja Kalevan lukijakommentit). On kuitenkin huomioitava, että anonymiteetin mahdollistavilla verkkokeskustelualustoilla kirjoittajien taustat eivät ole tiedossa.

Taulukko 1. Tutkimuksen aineisto

Aineisto kokonaisuudessaan

\begin{tabular}{lll}
\hline $\begin{array}{l}\text { Nuorten } \\
\text { verkkokeskustelut }\end{array}$ & Demi-foorumi: 64 keskusteluketjua & 30 keskusteluketjua \\
\hline Uutisartikkelit & $\begin{array}{l}\text { Yleisradion verkkosivu: 130 artikkelia, } \\
\text { joista 126 uutisartikkelia }\end{array}$ & 30 uutisartikkelia \\
\hline $\begin{array}{l}\text { Aikuisten } \\
\text { verkkokeskustelut }\end{array}$ & $\begin{array}{l}\text { Suomi24-foorumi \& sanomalehti } \\
\text { Kalevan juttutupa ja uutiskommentit: } \\
\text { 261 keskusteluketjua }\end{array}$ & $\begin{array}{l}\text { 20 Suomi24-foorumin ja 10 sanomalehti } \\
\text { Kalevan keskusteluketjua }\end{array}$ \\
\hline
\end{tabular}


Kuten diskurssianalyysissa yleisestikin, kielenkäyttöä analysoidaan tässä tutkimuksessa tapana tuottaa sosiaalista todellisuutta osana erilaisia sosiaalisia käytäntöjä, eikä kielenkäytön oleteta yksiselitteisellä tavalla kertovan puhujan tai kirjoittajan asenteista tai todellisuudesta (23). Tutkimuksen analyyttisena työkaluna käytetään asemointianalyysia (positioning analysis), jonka avulla tarkastellaan toimijoiden teksteissä tuottamia asemia itselle ja toisille $(8,9)$. Analyysissa huomio kohdistui erityisesti tapoihin, joilla toimijoita kuvaillaan ja niihin oikeuksiin, velvollisuuksiin ja vaatimuksiin, joita tiettyyn asemaan liitetään (8). Asemat ilmenevät aina suhteessa toisiinsa: kun toimija asemoi itseään, asemoi hän samalla muita toimijoita, ja päinvastoin asemoidessaan muita toimijoita, ihminen tulee asemoineeksi samalla itsensä $(8,9)$. Kognitiivisten auktoriteettien analyysissa nojataan aikaisempaan tutkimukseen biolääketieteellisestä, kokemuksellisesta ja yksilöllisestä kognitiivisesta auktoriteetista (17) sekä lähteisiin liittyvistä faktan konstruoimisen strategioista (18). Analyysin apuna käytettiin Nvivo 12 -ohjelmistoa, jonka avulla aineisto koodattiin kiinnittäen erityistä huomiota aineistokohtiin, joissa kuvattiin rokotuspäätöksenteon kannalta keskeisiä toimijoita ja tiedonlähteitä. Tämän jälkeen tunnistettuja asemia tarkasteltiin osana laajempaa tekstiä.

Tutkimuksessa on noudatettu hyvän tieteellisen käytännön periaatteita kuten yleistä huolellisuutta ja tarkkuutta tutkimustyössä (24). Erityistä huomiota kiinnitettiin keskustelufoorumeilta kerättyjen aineistojen käsittelyyn. Vaikka tutkimuksen kohteena olevat keskustelut ovat avoimilla foorumeilla kaikkien luettavissa, voi keskusteluun osallistujilla olla odotuksia niiden yksityisyydestä. Keskustelijoiden anonymiteetin turvaamiseksi keskustelujen tarkkoja päivämääriä, keskustelijoiden nimimerkkejä tai keskusteluketjujen otsikoita ei raportoida. Foorumeiden ylläpitäjiin otettiin lisäksi yhteyttä sen varmistamiseksi, että keskusteluaineistoja on hyväksyttävää käyttää tutkimusaineistona.

\section{TULOKSET}

HPV-rokotteeseen liittyvien uutistekstien ja verkkokeskusteluiden tarkastelu osoittaa kolme keskeistä toimijaa rokottamista koskevassa päätöksenteossa: rokotuksen kohteena oleva nuori, hänen vanhempansa ja terveysviranomainen. Keskeisiksi nousevia tiedonlähteitä luonnehditaan biolääketieteellisen, institutionaalisen, kokemuksellisen ja yksilöllisen kognitiivisen auktoriteetin käsitteillä. Seuraavissa alaluvuissa toimijoille tarjoutuvia asemia ja keskeisiksi nousevia kognitiivisen auktoriteetin muotoja käsitellään aineistoittain (uutistekstit, aikuisten verkkokeskustelut, nuorten verkkokeskustelut), jotta keskustelukontekstit tulevat huomioiduksi.

\section{UUTISTEKSTIT}

HPV-rokotetta käsittelevissä uutisartikkeleissa aktiiviseksi päätöksentekijäksi asemoidaan vaihtelevasti nuori, vanhempi ja terveysviranomainen. Yhdenmukaista teksteille on rokotemyönteinen puhetapa ja biolääketieteellisen kognitiivisen auktoriteetin vahvistaminen.

Terveysviranomaisten päätöksenteon kohteena nuoret näyttäytyvät usein määrällisenä joukkona pikemminkin kuin yksilöinä. Tilastotietoon perustuvien prosenttiosuuksien avulla voidaan osoittaa mikä on populaatiossa tyypillistä (25): "Lumijoella rokotetaan vuonna 2006 syntyneistä tytöistä 40,7, Hailuodossa 42,9, Tyrnävällä 45,3, Limingassa 46,1 ja Muboksella 56,2 prosenttia” (Yle 21.10.2019). Terveyden ja hyvinvoinnin laitos (THL), terveydenhoitajat ja muut viranomaiset mahdollistavat rokottamisen ja antavat rokotetta populaation jäsenille; terveysviranomaisten päätöksenteon kohteena nuoret "saavat" tai heille "annetaan" rokotus. Näissä kuvauksissa rokottamattomuudelle ei etsitä selityksiä yksilöistä. Velvollisuuteen rokottautua viitataan kuitenkin esimerkiksi puhumalla laumasuojasta, jonka syntymiseksi tarvitaan riittävä määrä rokotettuja nuoria: "Osallistumisprosentti ei ole tarpeeksi korkea, se on vasta 70 prosenttia, kun sen pitäisi olla 90 prosenttia” (Yle 7.3.2019).

Nuori voi olla myös vanhempiensa päätöksenteon kohde; vanhemmat tekevät päätöksen rokottamisesta tai rokottamattomuudesta, ja nuori on vanhempiensa ohjailtavissa: "Onko sinulla yläkouluikäinen nuori - annatteko bänelle HPVrokotteen?” (Yle 23.10.2013). Vanhemman päätöksentekijäasemaan viitataan myös epäsuorasti kuvaamalla vanhempien rokotteeseen liittyviä huolia. Rokotteen turvallisuuteen liittyvät huolet, sosiaalisessa mediassa liikkuneet huhut ja aiheen "herkkyys ja tunnepitoisuus" esitetään selityksenä kielteiselle rokotuspäätökselle. Vanhemman päätös kieltää rokotteen antaminen näyttäytyy kuitenkin epärationaalisena. Osa vanhemmista 
kuvataan toimijoina, joiden lapset tai he itse jäävät ilman syöpää ehkäisevää rokotetta: "Osa vanhemmista kieltää tytöiltään kohdunkaulan syöpää ehkäisevän rokotteen - "Yksi perustelu on, että meidän tyttö ei tule tarvitsemaan tätä" " (Yle 14.8.2018).

Aktiivisen päätöksentekijän asemassa nuoret tekevät valinnan rokotteen ottamisesta tai siitä kieltäytymisestä; nuoret "ottavat”, "ovat päättäneet ottaa" tai "haluavat" rokotteen, "suostuvat" ottamaan rokotteen tai "kieltäytyvät" siitä. Suoremmin asemaa kuvataan esimerkiksi toteamalla että "[t]oki yhdeksäsluokkalaiset tytöt tekevät jo tekevät päätöksen itse” (Yle 8.6.2018) ja ”[j]okainen on kuitenkin tehnyt valintansa itse, haluaako rokotetta ottaa vai ei" (Yle 27.5.2014). Selitykseksi nuorten rokotteesta kieltäytymiselle tarjotaan sosiaalisessa mediassa levinneitä huhuja rokotteen haitoista, "piikkipelkoa” sekä yleistä epäluuloa rokotteen turvallisuutta tai tarpeellisuutta kohtaan. Nuorten kohdalla epäsopivina tiedollisina vaikuttajina kuvataan myös kavereita, joiden mielipide tai valinnat ohjaavat tämän rokotuspäätöstä: "Sosiaalinen paine, kaveripiirin mielipide ja rokotteen ylle sikainfluenssarokotteen jälkimainingeissa laskeutunut epäilysten verho vaikuttavat tyttöjen päätöksiin” (Yle 20.11.2013).

Poikkeuksellisena aineistossa näyttäytyvät otteet, joissa kuvataan toimijoiden jaettua päätöksentekoa: "Rokotteesta lähtee tyttöjen koteihin kirjeet, jossa rokotteesta kerrotaan. Tytöt tekevät vanhempiensa kanssa päätöksen ottavatko rokotteen vai eivät. ... pohtii [terveysneuvonnan apulaisosastonhoitaja] Hanneli Seppänen” (Yle 30.9.2013). Jaettua päätöksentekoa koskevat kuvaukset esitetään uutisartikkeleissa yhdenmukaisesti lainauksina terveydenhuollon toimijoiden tai nuoren puheesta. Kuvauksissa viitataan HPV-rokotetta koskevaan keskusteluun nuoren, vanhempien ja kouluterveydenhoitajan välillä ja myös vanhemman ja nuoren yhteiseen tiedonhankintaan. Vaikka nuori näyttäytyy näissä teksteissä ensisijaisena päätöksentekijänä, voidaan vanhempi tai terveydenhuollon ammattilainen asettaa vastuuseen tiedonhankinnasta tai neuvonantajana toimimisesta:

"Hän [kouluterveydenhoitaja] patistaa vanhempia internetiin etsimään tietoa rokotteesta ja keskustelemaan siitä lastensa kanssa. - On vähän huolestuttavaa, että vanhemmat antavat tytön yksin päättää asiasta. Silloin nuoret tytöt eivät välttämättä osaa huomioida rokotteen hyötyjä ja toteavat vain, etteivät halua pistettäviksi” (Yle 19.11.2013)

Uutisteksteissä keskeiseen tiedolliseen asemaan nousevat yhdenmukaisesti biolääketieteellistä kognitiivista auktoriteettia edustavat terveydenhuollon ammattilaiset ja instituutiot sekä tutkimustieto. Vaikka journalistisen tasapainon normien noudattamisen on väitetty johtaneen siihen, että mediassa asiantuntijoiden rokotusmyönteiset ja ei-asiantuntijoiden rokotusvastaiset kannat saavat yhtä paljon näkyvyyttä $(26,27)$, eivät Ylen uutisteksteissä HPV-rokotusta vastustavat puheenvuorot saa huomiota. Uutisissa ääneen pääsevät kouluterveydenhoitajat, osastonhoitajat, ylihoitajat, terveydenhuollon päälliköt ja lääkärit, sekä THL:n asiantuntijat, joiden nimityksissä yhdistyy tavallisesti useita luottamusta herättäviä määreitä kuten professori, ylilääkäri ja johtaja. Lääkärin, tutkijan tai professorin asemaan tai instituutioihin kuten Terveyden ja hyvinvoinnin laitokseen tai Maailman terveysjärjestöön WHO:iin vetoamalla voidaan uutistekstien HPV-rokotusten tarpeellisuutta ja turvallisuutta korostavat argumentit oikeuttaa puhujakategorian perusteella $(17,18)$. Faktuaalista konsensusta rokotteiden turvallisuudesta vahvistetaan lisäksi vetoamalla erilaisiin tilastoihin ja tutkimukseen, jota on tehty sekä Suomessa että ulkomailla useiden vuosien ajan, tuhansien nuorten keskuudessa.

"Maailman terveysjärjestön WHO:n rokoteturvallisuuskomitea julkaisi kesällä raportin, jonka mukaan yli 175 miljoonan jaetun rokoteannoksen kokemuksella HPV-rokotteiden turvallisuudesta on kiistaton näyttö. Myös Suomessa Tampereen yliopisto on tutkinut HPV-rokotteiden tehoa ja turvallisuutta yli 25000 nuorella neljän vuoden ajan.” (Yle 30.10.2013)

Vaikka nuori ja vanhemmat asetetaan uutisteksteissä myös aktiivisiin päätöksentekijäasemiin, tavoitteena ei näyttäydy niinkään informoitu päätöksenteko, vaan viranomaisten päätöksiin mukautuminen. Epäsopivat, väärää ja uskomuksiin perustuvaa tietoa levittävät tiedonlähteet, "huhut", "kohu" ja "vääristyneet mielikuvat" ohjaavat nuor- 
ta tai vanhempia kieltäytymään rokotteesta, kun oikea valinta olisi rokotteen ottaminen.

"Vanhemmilta ei tarvitse enää tulevaisuudessa kysyä erillistä lupaa tyttöjen HPV-rokotusta varten ... THL arvioi, että luvan erikseen kysymisellä on merkitystä. Osalle vanhemmista tulee olo, että rokotetta täytyy harkita, pelätä tai miettiä. ... Terveydenhuoltoalan ammattilaisten mukaan osa vanhemmista hakee rokotustietoutta netistä, mutta eivät tule tarkistaneeksi tiedon luotettavuutta ja tekevät päätöksen huhupuheiden ja mielikuviensa varassa." (Yle 14.8.2018)

\section{AIKUISTEN VERKKOKESKUSTELUT}

Aikuisten verkkokeskusteluissa korostuu vanhemman päätöksentekijäasema, joka joissakin tapauksissa asettuu konfliktiin terveysviranomaisten aseman kanssa. Nuori saa melko yhdenmukaisesti päätöksenteon kohteen aseman; nuorella ei ole aktiivista roolia tai velvollisuuksia päätöksenteossa, vaan hänen tehtävänään on kantaa päätöksen seuraukset.

Sekä Suomi24-foorumilla että Kalevan verkkokeskusteluissa keskustelu on kärjistynyttä ja vastakkain asettuvat rokotusta vastustavat ja sitä puolustavat äänet, mitä on pidetty erityisesti sosiaalisen median rokotekeskusteluille tyypillisenä ilmiönä (28). Keskustelu kiinnittyy yhtäältä kasvatukselliseen debattiin ja toisaalta luottamukseen erilaisia rokottamistoiminnan kannalta keskeisiä toimijoita kohtaan.

Erityisesti kasvatusta koskevan keskustelun yhteydessä osoitetaan vastuuta vanhemmille lapsia koskevien valintojen tekemisessä. Vanhemman velvollisuutena on suojella lasta HPV-rokotteen haitoilta tai toisaalta rokottamattomuuden haitoilta. Samalla voidaan myös kyseenalaistaa muiden vanhempien pätevyyttä tehdä lasta koskevia päätöksiä.

\footnotetext{
"Kummalle haluat lapsesi altistaa: rokotteella estettävissä olevalle syövälle vai rokotteen haittavaikutuksille? Kumman vaihtoehdon kanssa pystyt elämään?” (Kalevan verkkokeskustelut tammikuu 2019)
}

Neuvottelu kohdistuu paitsi päätöksentekoon, myös vanhemman velvollisuuteen tiedon hankinnassa ja sen kriittisessä arvioinnissa. Etenkin Ka- levan lukijakommenteissa luottamus "perinteisiin" ja "vaihtoehtoisiin" kognitiivisiin auktoriteetteihin kietoutuu keskusteluissa yhteen kasvatuksellisten arvojen ja maailmankuvan kanssa. Vastapuolet asemoivat toisensa puhujakategorioihin $(17,18)$, joiden avulla voidaan mitätöidä esitettyjä väitteitä. Rokotetta vastustavien puheessa rokotetta kannattavat vanhemmat näyttäytyvät sinisilmäisinä; heiltä puuttuu kriittisyys viranomaisia ja muita perinteisiä auktoriteetteja kohtaan. Lisäksi he kannustavat nuoria vapaamielisesti seksin harrastamiseen ja altistavat lapsensa siten negatiivisille seurauksille. Myös rokotetta kannattavien puheessa rokotteen vastustaminen kytketään laajempaan maailmankatsomukseen: rokotevastaisuutta selittää keskusteluissa uskonto ja usko vaihtoehtohoitoihin ("käyttävät lääkkeinä inkiväärï ja ruokasoodaa”). Rokotteen vastustamiseen liitetään myös konservatiivisuus erityisesti seksiin liittyvissä kysymyksissä ("pitävät esiaviollista seksiä syntinä”).

Terveysviranomaisten päätöksentekijäasema näyttäytyy lähinnä sen vastustamisen kautta: Rokotusta vastustavassa puheessa terveysviranomaiset "pakkorokottavat" ja antavat "myrkkypiikin" vanhemmilta lupaa kysymättä. Keskusteluissa myös viitataan vanhemman päätöksentekijäaseman näennäisyyteen:

”Mutta kukin tietysti päättää itse. Jos päättää. Meillähän on lukkoonlyötynä kansallinen rokotusohjelma (11/2013 alkava), ja vastuullinen vanhemmuus on aukikirjoitettu sellaiseksi, että luotamme auktoriteetteihin (THL, STM).” (Suomi24 kesäkuu 2013)

Keskusteluissa keskeiseksi nousee neuvottelu rokotekampanjan taustalla olevien instituutioiden auktoriteettiasemasta. Vaikka osa näistä toimijoista, esimerkiksi THL, voidaan ymmärtää myös biolääketieteellisen kognitiivisen auktoriteetin edustajiksi, käytän niistä tässä yhteydessä nimitystä institutionaalinen kognitiivinen auktoriteetti, sillä keskustelu ei kohdistu niinkään biolääketieteelliseen tietoon vaan luottamukseen yhteiskunnallisia toimijoita kuten mediaa ja virkamiehiä kohtaan.

Sekä rokotetta puolustavia että sitä vastustavia väitteitä perustellaan biolääketieteelliseen tutkimustietoon vetoamalla. Rokotusta vastustavien puheessa HPV-rokotekampanjan taustalla 
olevien tahojen tarjoama informaatio kuitenkin näyttäytyy propagandana ja vääristelynä. Kyseenalaistaminen ei rajaudu ainoastaan terveydenhuollon toimijoihin vaan laajemminkin esimerkiksi mediaan, joka ei "tietenkään informoi” rokotteiden haitoista (Suomi24 huhtikuu 2013) ja painostaa rokotteen ottamiseen ("Kai ne sen rokotteen ottaa, kun on median kautta hirveä painostus sen ottamiseen" Suomi24 marraskuu 2013). Näiden instituutioiden kognitiivista auktoriteettia horjutetaan esimerkiksi esittämällä väitteitä korruptiosta ja toimijoiden osallisuudesta salaliittoihin: "Todella törkeää toimintaa Terveydentuboamislaitokselta! PELKÄSTÄÄN TALOUDELLISTA ETUA johtoporras siellä ajattelee” (Suomi24 kesäkuu 2013).

Puhetapa noudattelee aikaisemmissa tutkimuksissa esitettyjä, rokotekriittiselle diskurssille ominaisia piirteitä kuten viranomaistoimijoiden pätevyyden tai intressien kyseenalaistamista (19, $21,17,18)$. Vastinpariksi institutionaaliselle kognitiiviselle auktoriteetille nousee omaan päättelyyn ja arvoihin perustuva yksilöllinen auktoriteetti (17): omaa auktoriteettia vahvistetaan erityisesti esittämällä väitteitä faktana (minulla on auktoriteettia koska minulla on tietoa) (19) ja vetoamalla itse etsittyyn tietoon.

"Vähintäänkin ottakaa asioista huolella selvää älkääkä sokeasti uskoko THL:n ja rokotefirmojen propagandaa. Kyseessä on taas kerran isot rahat. Suojelkaa lapsianne turhien rokotusten haitoilta, jotka voivat olla kohtalokkaita.” (Kalevan verkkokeskustelut lokakuu 2013)

Vastaavasti yksilölliseen auktoriteettiin vedotaan myös rokotusta ja institutionaalista auktoriteettia puolustavissa puheenvuoroissa.

Suomi24-foorumilla HPV-rokotuksen negatiivisia seurauksia koskeva lyhyt viesti yhdistyy usein kansainväliselle tai kotimaiselle ns. vaihtoehtoiselle uutissivustolle ohjaavaan linkkiin:

”Japanissa näiden HPV-rokotteiden pakkorokotukset aloitettiin jo aiemmin ja siellä ne ovat jo tutkitusti aiheuttaneet hedelmättömyyttä ja pitkäaikaista kivuntunnetta. Nyt Japanin hallitus haluaa lakkauttaa koko HPVrokoteohjelman. Tässä lukekaa itse Lähteet: [linkki naturalnews.com -sivustolle]" (Suomi24 marraskuu 2013)

Linkittäminen palvelee väitteen vahvistamista; väite ei perustu ainoastaan omaan käsitykseen, vaan sen takana on verifioitavissa oleva lähde (19). Useita eri lähteitä linkittämällä voidaan saada aikaan mielikuvaa riippumattomien toimijoiden konsensuksesta (18). HPV-rokotetta puolustavissa puheenvuoroissa rokotusvastaisia lähteitä kyseenalaistetaan ja niiden vastinpariksi esitetään lainauksia tai linkkejä uutislähteille kuten Yleisradion uutisiin. Sekä lähteiden että toisten keskustelijoiden auktoriteettia heikennetään lisäksi puhujakategoriaan perustuvalla vähättelyllä (17, 18), esimerkiksi asettamalla puhuja "salaliittoteoreetikon" tai "lääkefirman trollin" kategoriaan.

\section{NUORTEN VERKKOKESKUSTELUT}

Nuorten verkkokeskusteluissa nuoret asemoivat itsensä ja toisensa yhdenmukaisesti aktiivisiksi päätöksentekijöiksi, jotka "ottavat", "ottivat” tai "eivät ottaneet" rokotetta. Keskusteluissa etualalle nousee päätöksenteon käytännöllisyys ja välittömät vaikutukset kuten kipu ja "piikkikammo" ja rokottamiseen liittyvät tuntemukset. Nuori ei ainoastaan tee päätöstä vaan kantaa myös sen seuraukset: "Itse otin sen rokotteen viime vuonna ja mullakin on aivan hirvee neula/rokotus kammo.Kyllä vieläkin pistää kylmät väreet tulemaan ku ajattelee sitä rokotusta” (Demi syyskuu 2017).

Vaikka nuori asemoidaan itsenäiseksi päätöksentekijäksi, tarjoutuu vanhemmalle tai terveydenhuollon ammattilaiselle joissakin tapauksissa asema neuvonantajana, joka voi ohjata nuorta päätöksenteossa. Poikkeuksellisena näyttäytyvät muutamat aineisto-otteet, joissa viitataan jaettuun päätöksentekoon: "Meillä kans mun vanhemmat oli vastaan mutta äiti jutteli terkkarin kans ja sit sai sen pään kääntymään. Ja kyllä mää ite halusin ottaa sen, mutta äiti ja isi oli vastaan” (Demi maaliskuu 2015).

Etualalle nuorten keskusteluissa nousevat kokemuksen varaan rakentuvat kokemuksellinen ja yksilöllinen auktoriteetti. Rokotteen jo saaneilla nuorilla on kokemustietoa, jota he voivat hyödyntää selviytymiskeinojen tarjoamiseen toisille ja näin rakentaa asemaansa kokemuksellisena kognitiivisena auktoriteettina (17). 
"Ei ole pakko ottaa mutta sinuna kyllä ottaisin:) Monet mun luokkalaiset tytöt otti vaikka niillä oli piikkikammo ja mäkin otin. Et vaan kato sitä neulaa ja voit pyytää jonkun kaverin sun mukaan sinne:) Se itse rokotus ei satu ja jälkioireet sen jälkeen on useimmiten heikot. Ja sehän otetaan kaksi kertaa ja niiden kahden kertojen välissä on noin 5 kuukautta. Mutta sinuna ottaisin sen ehdottomasti! Tsemppiä<3" (Demi kesäkuu 2019)

Väitteitä vahvistetaan konsensuksella (17): mielipiteen tueksi esitetään sekä oma että muiden samassa tilanteissa olleiden valinnat. Sosiaalisen median lähteet, tietyt medialähteet ja kaverit sen sijaan asetetaan melko yhdenmukaisesti kyseenalaiseen valoon. Kiinnostavaa on, että samalla kun näiden lähteiden luotettavuus kyseenalaistetaan, tiedon hankkiminen itse Googlen avulla voidaan esittää luotettavuutta vahvistavana argumenttina. Tämä voidaan tulkita yksilöllisen auktoriteetin ilmenemismuodoksi. Yksilöllistä auktoriteettia vahvistetaan lisäksi vetoamalla omaan päättelyyn (17): ”Tietysti riski on olemassa, mutta saatahan liukastua kadulla ja halkaista kallosi? Jos kuitenkin ajateltaisiin terveellä järjellä. Taino mitää mä muista välitän, itsehän mulla jo on se kohdunkaulasyövän suoja :)” (Demi lokakuu 2013).

Huomioitavaa on, että nuorten keskusteluissa kokemuksellisen ja yksilöllisen auktoriteetin avulla ei pääsääntöisesti haasteta biolääketieteellistä tai institutionaalista auktoriteettia. Harvat rokotuksiin kategorisen kielteisesti suhtautuvat kommentit eivät saa laajaa kannatusta, vaan vallalla on rokotusmyönteinen puhetapa. Rokotus- myönteistä kantaa puolustetaan tiukastikin ja rokotusta vastustavia puheenvuoroja vähätellään asettamalla puhuja "foliohattu" tai "idioot$t i$ ”-puhujakategorioihin $(19,24)$ : "Oletko ihan vitun idiootti? Papa-kokeissa käyminen ei pelasta kohdunkaulansyövältä, mutta rokote voi pelastaa. t. Rokotuksen saanut ja hyvinvoiva” (Demi lokakuu 2013). Aikuisten keskusteluissa ilmennyttä jyrkkää kahtiajakoa rokotusmyönteisten ja -kielteisten välille ei nuorten keskustelussa kuitenkaan muodostu. Myös linkit rokotekriittisille mediasivustoille puuttuvat nuorten keskusteluista kuten Virtanenkin huomioi (13). Sen sijaan keskusteluissa viitataan yleisemmällä tasolla institutionaaliseen kognitiiviseen auktoriteettiin kuten valtioon ja kouluun luotettavina toimijoina.

”Tietysti KAIKISSA rokotteissa riski on, mutta tuskinpa lääketeollisuus tätä päästäisi markkinoille jos kaikki siihen kuolisivat? Ja hyvähän sen valtion on tunkea paskaaa, kun hehän se mn joutuvat maksamaan! Eli heti kun tämä rokote on lisätty rokotusohjelmaa, täyttyy iltalehti ym. tästä "tämärokotetappaakaikkiäläota!!1”” (Demi lokakuu 2013)

\section{POHDINTA}

Tutkimus osoittaa kolme keskeistä toimijaa HPVrokotuspäätöksen tekemisessä - nuori, hänen vanhempansa ja terveysviranomainen - ja tukee siten käsitystä siitä, että rokotuspäätös jakautuu useiden eri toimijoiden kesken (14). Analyysin keskeiset tulokset on koottu yksinkertaistettuna Taulukkoon 2.

Taulukko 2. Yhteenveto keskeisistä tuloksista aineistoittain.

\begin{tabular}{lccc} 
Aineisto & Uutisartikkelit & Aikuisten keskustelut & Nuorten keskustelut \\
\hline $\begin{array}{l}\text { Rokotus- } \\
\text { päätöksen tekee }\end{array}$ & $\begin{array}{c}\text { Viranomainen / vanhempi } \\
\text { / nuori }\end{array}$ & $\begin{array}{c}\text { Vanhempi / } \\
\text { viranomainen }\end{array}$ & Nuori \\
\hline $\begin{array}{l}\text { Merkitykselliset } \\
\text { kognitiiviset } \\
\text { auktoriteetit }\end{array}$ & Biolääketieteellinen & $\begin{array}{c}\text { Yksilöllinen / } \\
\text { institutionaalinen }\end{array}$ & Kokemuksellinen, yksilöllinen \\
\hline
\end{tabular}


Tulokset osoittavat HPV-rokotukseen liittyvän keskustelun moniulotteisuutta. Uutisteksteissä aktiivisiksi päätöksentekijöiksi asemoidaan vaihtelevasti nuori, tämän vanhemmat ja terveysviranomaiset. Rokottamisen tarpeen perustelussa ne nojaavat yhdenmukaisesti biolääketieteelliseen kognitiiviseen auktoriteettiin ja toistavat suomalaisen HPV-rokotekampanjan keskeistä viestiä, jonka mukaan HPV-rokote on tieteellisesti todistettu, turvallinen suoja tappavalle syövälle (13). Vanhemman tai nuoren rokotteesta kieltäytyminen näyttäytyy epärationaalisena, ennakkoasenteisiin ja epäluotettavaan tietoon perustuvana ratkaisuna (ks. myös 11), ja asettuu siten konfliktiin rokotteen tarvetta perustelevan biolääketieteellisen, "oikean" tiedon kanssa.

Aikuisten verkkokeskusteluissa vanhemman päätöksentekijäasema korostuu ja nuoret näyttäytyvät yksinomaan päätöksenteon kohteina. Kärjistynyt keskustelu ei kohdistu niinkään biolääketieteelliseen tietoon kuin yleisempiin maailmankatsomuksellisiin kysymyksiin, erityisesti luottamukseen yhteiskunnan keskeisiä instituutioita kuten terveydenhuoltoa ja julkista mediaa kohtaan. Vastakkain näyttävät asettuvan institutionaaliseen ja yksilölliseen kognitiiviseen auktoriteettiin vetoaminen. Erityisesti pohjoissuomalaisen Kaleva-sanomalehden lukijakommenttien kasvatukseen liittyvässä keskustelussa arvoihin ja maailmankuvaan liittyvä puhe kietoutuu keskusteluun paitsi luotettavista tiedonlähteistä myös sopivasta seksuaalisesta käyttäytymistä, vaikka Euroopassa tällaista puhetapaa ei ole pidetty tavallisena (29-34).

Toisin kuin aikaisemmissa tutkimuksissa, joissa HPV-rokotteen saaneet tytöt asemoivat rokotuspäätöksen tekijöiksi vanhempansa (12) tai kuvasivat päätöstä nuoren ja vanhemman yhteiseksi (11), Demi-foorumilla korostuu tyttöjen itsenäisen päätöksentekijän asema. Tytöille ja nuorille naisille suunnattu keskustelupalsta tarjoaa alustan rokotukseen liittyvän kokemustiedon jakamiseen (35) ja keskeiseksi nouseekin yhtäältä kokemuksellinen ja toisaalta yksilöllinen kognitiivinen auktoriteetti. Nuorten keskusteluissa nämä eivät kuitenkaan asetu haastamaan biolääketieteellistä auktoriteettia.

Tutkimus tukee McKenzien (17), Genuisin (22) ja Dotyn (19) esittämiä huomioita kontekstuaalisista tavoista rakentaa tiedonlähteiden kognitiivista auktoriteettia: erityisesti puhujakatego- riaan vetoaminen $(19,17)$ ja epäsopivien intressien osoittaminen $(19,17)$ olivat tämänkin tutkimuksen perusteella tavallisia keinoja vahvistaa tai heikentää lähteiden auktoriteettiasemaa. Keinot kuitenkin vaihtelivat eri aineistoissa. Uutisissa asiantuntemusta osoittava puhujakategoria (professori, tutkija, lääkäri) ja tutkimustietoon perustuva konsensus olivat tavallisia tapoja perustella väitteitä. Aikuisten verkkokeskusteluissa konsensusta luotiin linkkien avulla ja tautologisella, samaa näkemystä vahvistavien lähteiden esittämisellä ja lähteiden auktoriteettia horjutettiin puhujakategorian perusteella. Nuorten keskusteluissa yksittäiset mielipiteet ja kokemukset loivat mielikuvaa useiden riippumattomien toimijoiden konsensuksesta. Verkkokeskusteluissa oman kognitiivisen auktoriteetin vahvistamiseen käytettyjä keinoja olivat väitteen esittäminen faktana, lähteisiin viittaaminen ja valtuuttaminen puhujakategorian, esimerkiksi ammatin tai kokemuksen, perusteella.

Kuten Genuisin (22) tutkimuksessa, näyttävät päätöksentekijöiden ja kognitiivisten auktoriteettien asemat tämänkin tutkimuksen perusteella linkittyvän. HPV-rokotuksen kohdalla asetelma on kuitenkin erityisen kompleksinen, sillä toimijat asettuvat erilaisiin asemiin paitsi suhteessa tiedonlähteisiin myös suhteessa toisiinsa. Tulevissa tutkimuksissa onkin syytä tarkastella ilmiötä tarkemmin erityisesti autenttisissa jaetun päätöksenteon tilanteissa. Tutkimus HPV-rokotuspäätökseen vaikuttavista tekijöistä Suomessa on toistaiseksi vähäistä ja alueelliset erot rokotekattavuudessa merkittäviä (3). Siksi on tarpeellista tutkia HPV-rokotediskursseja paikallisesti. Myös julkisen keskustelun tarkastelu on edelleen kiinnostavaa erityisesti tilanteessa, jossa poikien HPVrokotukset ovat tulleet osaksi kansallista rokotusohjelmaa (2). Tarkastelemalla tunnistettuja puhetapoja sekä julkisessa keskustelussa että paikallisesti voidaan paremmin ymmärtää HPV-rokotuspäätöksen tekemistä paitsi yksilön valintana, myös seurauksena erilaisista yhteisöllisistä ja yhteiskunnallisista tekijöistä, jotka yhdessä tekevät päätöksenteon mahdolliseksi (36).

Tämän tutkimuksen tuloksia ei voida suoraan yleistää tarkasteltujen kontekstien ulkopuolelle, sillä puhetavat ovat kontekstisidonnaisia ja rakentuvat osana laajempia käytäntöjä. Uutistekstien ja valittujen verkkokeskustelualustojen piirteet ohjaavat niillä käytyä keskustelua, eivät- 
kä ne siten kuvasta esimerkiksi nuorten tai aikuisten HPV-rokotetta koskevaa puhetta muissa tilanteissa.

Tulokset voivat auttaa kiinnittämään huomiota paitsi toimijoille päätöksentekotilanteissa tarjoutuviin asemiin, myös tiedontarpeisiin, joihin erilaiset tiedolliset auktoriteetit voivat vastata. Rokottamattomuuden taustalla olevat moninaiset syyt voivat siten tulla paremmin huomioiduksi. Käytännön toimijat voivat ottaa tulokset huomioon HPV-rokotukseen liittyvän viestinnän ja ohjauksen suunnittelussa. Erityisesti nuorten ja vanhempien kanssa työskentelevillä terveydenhuollon ammattilaisilla voi olla merkityksellinen asema rokotuspäätöksen tukemisessa ja erilaisiin tiedontarpeisiin vastaaville lähteille ohjaamisessa. Tuloksia on mahdollista hyödyntää myös pohdittaessa tietoon perustuvan suostumuksen (informed consent) ja myöntymyksen (assent) kysymyksiä HPV-rokotuksen yhteydessä.

\section{KIITOKSET:}

Kiitän artikkelin arvioijia heidän arvokkaista kommenteistaan.

\section{RAHOITTAJAT:}

Tutkimusta on rahoittanut Suomen Akatemia (n:o 321266).

\section{Hirvonen, N. Whose decision? Participants' positions and cognitive authorities in HPV vaccine discussion. Sosiaa- lilääketieteellinen aikakauslehti - Journal of Social Medicine 20 I9: 56: 228-240.}

Human papilloma virus (HPV) vaccines are used to prevent HPV infections and associated diseases, especially cervical cancer. In Finland, the vaccine is included in the national vaccination program and is offered to adolescents free of charge. Focusing on HPV vaccination discourses, this study asks: 1 . Who are the key vaccination decision-makers and how are they positioned and 2. what kind of information sources are constructed as authoritative in this context? The material for the study comprises of Finnish news articles and online discussion threads, which were analysed using positioning analysis. The study shows that young people, their parents, and health au-

\section{LÄHTEET}

(1) Maver J, Poljak M. Progress in prophylactic human papillomavirus (HPV) vaccination in 2016: A literature review. Vaccine 2018;36(3628):5416-5423. doi: 10.1016/j.vaccine.2017.07.113

(2) Terveyden ja hyvinvoinnin laitos THL. Tulisiko poikien HPV-rokotusten olla osa kansallista rokotusohjelmaa? Työryhmän loppuraportti. Helsinki: THL;2019.

http://urn.fi/URN:ISBN:978-952-343-282-6

(3) Terveyden ja hyvinvoinnin laitos THL. HPVrokotuskattavuus. Päivitetty 30.10.2019 https:// thl.fi/fi/web/infektiotaudit-ja-rokotukset/ rokotteet-a-o/hpv-eli-papilloomavirusrokote/hpvrokotuskattavuus

(4) Riikola, T. Mitä toimittajilta jäi rokotekohussa kertomatta? Tiedetoimittaja 2014;4. Luettu 1.7.2020. thorities are alternatingly positioned as active decision-makers. Biomedical, institutional, experiential, and individual cognitive authorities stand out as pivotal for decision-making, and they are both supported and challenged in different ways in the discussions. The study highlights the need to further explore vaccination decision as the result of shared decision-making among multiple participants.

Keywords: vaccines, decision-making, discourse, information sources.

Saapunut 31.03 .2020

Hyväksytty 19.08 .2020 http://www.tiedetoimittajat.fi/mita-toimittajiltajai-rokotekohussa-kertomatta/

(5) Karafillakis E, Simas C, Jarrett C ym. HPV vaccination in a context of public mistrust and uncertainty: A systematic literature review of determinants of HPV vaccine hesitancy in Europe. Hum Vaccin Immunother 2019;15(78):1615-1627. doi: 10.1080/21645515.2018.1564436

(6) eoak 5294/2013 HPV-rokotuskampanjan toimeenpano / Implementering av ringen av en HPV vaccineringskampanj. Luettu 1.7.2020. https://www.eduskunta.fi/eoaratkaisut/ eoak+5294/2013

(7) THL. HPV- eli papilloomavirusrokote. Päivitetty 26.6.2020.

https://thl.fi/fi/web/infektiotaudit-ja-rokotukset/ rokotteet-a-o/hpv-eli-papilloomavirusrokote 
(8) Harré R, van Langenhoven L. Positioning Theory. Oxford: Blackwell;1999.

(9) McVee MB. Positioning Theory and sociocultural perspectives: Affordances for educational researchers. Kirjassa: McVee MB, Brock CH, Glazier JA (toim.) Sociocultural positioning in literacy: Exploring culture, discourse, narrative, and power in diverse educational contexts. Cresskill, NJ: Hampton Press; 2011, 1-22.

(10) Burns K, Davies C. Constructions of young women's health and wellbeing in neoliberal times: A case study of the HPV vaccination program in Australia. Kirjassa: Wright K, McLeod J (toim.) Rethinking youth wellbeing. Singapore: Springer; 2015, 71-89. doi: 10.1007/978-981-287-188-6_5

(11) Cooper Robbins SC, Bernard D, McCaffery K ym. "I just signed": Factors influencing decisionmaking for school-based HPV vaccination of adolescent girls. Health Psychol 2010;29(6):618625.

doi: $10.1037 / \mathrm{a} 0021449$

(12) Rail G, Molino L, Fusco C ym. HPV vaccination discourses and the construction of "at-risk" girls. Can J Public Health 2018;109(5-6): 622-632. doi: 10.17269/s41997-018-0108-8

(13) Virtanen MJ. "What kind of 'a girls' thing'? Frictions and continuities in the framing and taming of the HPV vaccine in Finland." Sociol Health Illn 2019;41(4):789-805. doi: 10.1111/1467-9566.12853

(14) Lindén L. Communicating Care: The Contradictions of HPV Vaccination Campaigns. Lund: Arkiv Academic Press; 2016. doi: 10.3384/diss.diva-127638

(15) Lefevre H, Samain S, Ibrahim N ym. HPV vaccination and sexual health in France: Empowering girls to decide. Vaccine 2019;37(13):1792-1798. doi: 10.1016/j.vaccine.2019.02.020

(16) Wilson P. Second-Hand Knowledge: An Inquiry into Cognitive Authority. Greenwood, Westport, CT; 1983.

(17) McKenzie P. Justifying cognitive authority decisions: Discursive strategies of information seekers. Libr Q 2003;73,261-288. doi: $10.1086 / 603418$

(18) Potter J. Representing reality: Discourse, rhetoric, and social construction. Thousand Oaks, California: Sage; 1996. doi: $10.4135 / 9781446222119$

(19) Doty C. Social epistemology and cognitive authority in online comments about vaccine safety, in iConference 2015 Proceedings, http://hdl.handle.net/2142/73664

(20) Neal DM, McKenzie PJ. Putting the pieces together: Endometriosis blogs, cognitive authority, and collaborative information behavior. J Med Libr Assoc 2011;99(2):127-13. doi: 10.3163/1536-5050.99.2.004

(21) Ma J, Stahl L. A multimodal critical discourse analysis of anti-vaccination information on
Facebook. Libr Inf Sci Res 2017;39:303-310. doi: 10.1016/j.lisr.2017.11.005

(22) Genuis SK. Social positioning theory as a lens for exploring health information seeking and decision making. Qual Health Res 2013;23(4):555-67. doi: $10.1177 / 1049732312470029$

(23) Jokinen A, Juhila K \& Suoninen E. Diskurssianalyysi. Teoriat, peruskäsitteet ja käyttö. Tampere: Vastapaino; 2016.

(24) Tutkimuseettinen neuvottelukunta. Ihmiseen kohdistuvan tutkimuksen eettiset periaatteet ja ihmistieteiden eettinen ennakkoarviointi Suomessa; 2019. https://www.tenk.fi/sites/tenk.fi/ files/Ihmistieteiden_eettisen_ennakkoarvioinnin_ ohje_2019.pdf

(25) Räisänen U. Masentuneet nuoret mediassa: riskiryhmiä ja masennuksen orjia.

Kirjassa: Modinos T, Suoninen A. (toim.)

Merkillinen media. Tekstit nuorten arjessa. Jyväskylä: Jyväskylän yliopisto, Soveltavan kielentutkimuksen keskus; 2003.

(26) Dixon GN, Clarke CE. Heightening uncertainty around certain science: Media coverage, false balance, and the autism-vaccine controversy. Sci Commun 2013;35(3):358-382. doi: 10.1177/1075547012458290

(27) Motta M, Callaghan T, Sylvester S. Knowing less but presuming more: Dunning-Kruger effects and the endorsement of anti-vaccine policy attitudes. Soc Sci Med 2018;211,274-281. doi: 10.1016/j.socscimed.2018.06.032

(28) Schmidt AL, Zollo F, Scala A ym. Polarization of the vaccination debate on Facebook. Vaccine 2018;36(25):3606-3612. doi: 10.1016/j.vaccine.2018.05.040

(29) Johnson E. Refracting through technologies: Bodies, medical technologies and norms. New York: Routledge; 2020. doi: $10.4324 / 9781315122274$

(30) Charles N. Injecting and rejecting, framing and failing. Fem Med Stud 2014;14(6):1071-1089. doi: 10.1080/14680777.2014.882855

(31) Cayen L, Polzer J, Knabe S. Tween girls, human papillomavirus (HPV), and the deployment of female sexuality in English Canadian magazines. Kirjassa: Polzer J, Power E (toim.) Neoliberal governance and health: Duties, risks, and vulnerabilities; Montreal, Kingston: McGillQueen's University Press; 2016, 82-107.

(32) Polzer J, Knabe S. Good girls do...get vaccinated: $\mathrm{HPV}$, mass marketing and moral dilemmas for sexually active young women. J Epidemiol Community Health 2009;63;869-870. doi: 10.1136/jech.2008.084509

(33) Casper MJ, Carpenter LM. Sex, drugs, and politics: the HPV vaccine for cervical cancer. Sociol Health Illn 2008;30(6):886-99. doi: 10.1111/j.1467-9566.2008.01100.x

(34) Mamo L, Nelson A, Clark A. Producing and protecting risky girlhoods: How the HPV vaccine became the right tool to prevent cervical cancer. Kirjassa: Wailoo K, Epstein S, Julia Livingston 
J, Robert Aronowitz R (toim.) Three shots at prevention: The HPV Vaccine and the Politics of Medicine's Simple Solutions. Baltimore: The Johns Hopkins University Press; 2010, 121-145.

(35) Hirvonen N, Tirroniemi A, Kortelainen T. The cognitive authority of user-generated health information in an online forum for girls and young women. J Doc 2019;75(1):78-98, doi: 10.1108/JD-05-2018-0083
(36) Scollon R, Scollon SW. Nexus analysis: Discourse and the emerging Internet. London: Routledge; 2004.

doi: $10.4324 / 9780203694343$

Noora Hirvonen

FT, tutkijatohtori

Oulun yliopisto

Informaatiotutkimus 